\title{
Modulation of Monosodium Glutamate Induced Histological Injuries, Histomorphometrical Alterations and DNA Damage in the Mice Hepatic and Renal Tissues by Oral Administration Nano- Cerium Oxide and L-arginine and their Combination
}

Original Article

\author{
Sherin R. Hamad ${ }^{1}$ and Hanan Ramadan Hamad Mohamed ${ }^{2}$ \\ ${ }^{1}$ Department of Histopathology, National Organization for Drug Control and Research \\ (NODCAR), Cairo, Egypt; \\ ${ }^{2} Z$ oology Department, Faculty of Science, Cairo University, Cairo, Egypt
}

\begin{abstract}
Background: Monosodium glutamate is widely used as flavor enhancer/food additive. Many studies confirmed toxicity of monosodium glutamate even if in low concentrations especially in hepatic and renal organs. Therefore, our study aimed to examine ameliorative role of Nano-cerium oxide and L-arginine and their combination on the hepatic and renal toxicity induced by monosodium glutamate.

Materials and Methods: Fifty mice were divided into five groups; 1st group served as control group; 2nd group treated oral with monosodium glutamate; animals of the 3rd group were administrated with monosodium glutamate and L-arginine. The 4th group was treated with monosodium glutamate and Nano-cerium oxide; and mice of the 5th group were treated with monosodium glutamate, L-arginine and Nano-cerium oxide. After 14 days, hepatic and renal tissues were removed for histological and histomorphometrical examinations

Results: Histological examination revealed hepatic and renal damages for animals treated with monosodium glutamate as well as highly significant declining of DNA content compared to control group. Administration of Nano-cerium oxide or L-argentine alone induced ameliorations of the hepatic and renal injuries induced by administration of monosodium glutamate but some pathological alterations still present. It also caused moderate improvement in the DNA content but still not reaches to normal value. Combined administration of Nano-cerium oxide and L-arginine caused marked ameliorations of the hepatic and renal changes induced by monosodium glutamate.

Conclusions: The combined uses of L-arginine and Nano-cerium oxide more effective in preventing the hepatic and renal toxicity induced by monosodium glutamate in male albino rats than when they uses separately.
\end{abstract}

Received: 29 January 2020, Accepted: 07 March 2020

Key Words: DNA content, histological, L-arginine, monosodium glutamate, nano-cerium oxide.

Corresponding Author: Sherin R. Hamad, PhD, Department of Histopathology, National Organization for Drug Control and Research (NODCAR), Cairo, Egypt, Tel.: +20 1001666593,E-mail: manaa_82@yahoo.com

ISSN: 1110-0559, Vol. 43, No.4

\section{INTRODUCTION}

Monosodium glutamate is the sodium salt of the amino acid glutamic acid and is considered as one of most food additives/flavor enhancer ${ }^{[1]}$ to intensify the meaty, savory flavor of food ${ }^{[2]}$. Naturally, glutamic acid (glutamate), can locate in many types of foods as meat, seafood (fish), milk, cheeses, poultry and some vegetables ${ }^{[3]}$, and also is present in most tissues while commercially is made from the fermentation of molasses, and present in fermented proteins, as soy sauce and hydrolyzed vegetable protein ${ }^{[4]}$ It also now produced in commercial quantities by bacterial fermentation ${ }^{[5]}$.

Monosodium glutamate is considering as most common a food additive that is selling in many countries with trade names Ajinomoto, Chinese salt, and E621. It is usually used in many food products such as noodles, flavored potato chips, many food snacks, canned sauces or soups, marinated meats, frozen foods and stuffed or prepared chicken ${ }^{[5-6]}$. In addition to, it greatly utilize within home and food industries, as well as fast foods and restaurant cooking ${ }^{[6-7]}$. Daily dietary composition of glutamate varies from one race to another, as daily oral consumption ranges from $0.5 \mathrm{mg} / \mathrm{kg}$ amongst Americans and over $3 \mathrm{~g} / \mathrm{kg}$ in Taiwanese diets ${ }^{[8-9]}$. However, oral consumption of monosodium glutamate in mice at doses within the Acceptable Daily Intake (0.5, 1.0 and 1.5 $\mathrm{mg} / \mathrm{kg} \mathrm{BW})$ ) were promoted hepatic and renal injuries ${ }^{[10]}$. Experimental studies were reported renal toxicity $(4 \mathrm{mg} /$ $\mathrm{kg} . \mathrm{bw})$ and hepatotoxicity (5mg/kg.bw) of monosodium glutamate at low concentration as evidences by histological, immumohistochemical and ultrastructure ${ }^{[11-12]}$. Likewise, Kumbhare et al. ${ }^{[13]}$ stated that monosodium glutamate at the 
dose $3 \mathrm{mg} / \mathrm{kg}$ bw induced conspicuous pathological lesions in the hepatic tissue when it was administrated orally for 45 successive days.

Recently, nanotechnology has been interested with biomedical research ${ }^{[14-15]}$ for example, One of the most interesting nanomaterial is cerium oxide nanoparticles ${ }^{[16]}$. Cerium oxide nanoparticles formed of cerium atoms bind with oxygen atoms, and widely used in commercial, industrial, and biological applications ${ }^{[17-18]}$. It common applied in different applications as therapy applications ${ }^{[16]}$, producing oxygen sensors ${ }^{[19]}$ automotive catalytic converters ${ }^{[20]}$ and so on, these referred to due to its catalytic properties ${ }^{[16]}$, as well as its redox capability, and antioxidant properties that scavenge free radicals ${ }^{[21]}$ and protect against oxidative stress ${ }^{[22]}$.

Safety of cerium oxide nanoparticles was recorded by, several studies as ${ }^{[23]}$, who reported non-toxicity of 2,000 $\mathrm{mg} / \mathrm{kg}$ body weight of cerium oxide nanoparticles oral administrated per daily. Also, non-toxicity of cerium oxide nanoparticles on rat retina cells ${ }^{[24]}$, and macrophages ${ }^{[25]}$, and were also approved. Similarity, Khorrami et al., ${ }^{[26]}$, showed that cerium oxide nanoparticles have antioxidant activity caused no significant changes in the activity of hepatic enzymes, hepatic and renal histopathology and hematological parameters, as well as significantly improved serum redox status, oxidative stress markers when animals treated intraperitoneally with cerium oxide nanoparticles in dose $50,100,200$, and $400 \mathrm{mg} / \mathrm{kg}$ in 14 consecutive days. Moreover, Srinivas et $a l^{[27]}$ also stated that cerium oxide nanoparticles did not cause any unsafe effects on hepatic and renal functions as well as hematology in rats treated with cerium oxide at14-day. Likewise, Amiri, et al. ${ }^{[28]}$ cerium oxide nanoparticle at dose $100 \mu \mathrm{g} / \mathrm{kg}$ for 3 days, intraperitoneally decline malondialdehyde level, elevate GSH level and decreased hepatic enzyme levels in Cyclophosphamide-treated mice. He reported also that cerium oxide nanoparticle pretreatment could be alleviated the immunoreactivity of caspase- 3 in cyclophosphamide -treated mice compared with the Cyclophosphamide group.

L-Arginine is one of the major amino acid in the diet of human, and is abundant in natural foods as dairy products, nuts, sea foods, wheat flour, and seeds. It consider as essential biologically compounds in cellular homeostasis and function. L-Arginine considered as a principle source for nitric oxide (NO) generation through NO synthase $(\mathrm{NOS})^{[29-30]}$ In experimental animals, different benefits effect of L-Arginine as enhancement of renal function markers, cardiovascular (Popolo, 2014) ${ }^{[31]}$, and enhances the immune status $)^{[32]}$ were reported. Elbassuonia, et al., ${ }^{[33]}$, stated that L-Arg (200 mg / kg body weight) has high ability to suppress the high food intake and gain of body weight induced by ingestion of monosodium glutamate $(35 \mathrm{mg} / \mathrm{kg} / \mathrm{d})$ as well as prevent histological lesions in hepatic and renal of animals treated with monosodium glutamate.

Moreover, supplementation of arginine in diet of female mice, prevent inflammation and development steatohepatitis in alcoholic model ${ }^{[34]}$. It also prevents renal toxicity of ethanol as manifested by morphological and histological studies in male $\operatorname{rats}^{[35]}$. Similarity, Badawoud1 et al., ${ }^{[36]}$ reported that L-arginine at dose level $378 \mathrm{mg} / \mathrm{rat} / \mathrm{day}$ for 4 weeks has effective ability to improve biochemical and histological changes in 5-5-fluorouracil nephrotoxicity, as glomerulus sclerosis, degeneration of convoluted tubules and interstitial fibrosis.

Therefore, current work aimed to examine ameliorative role of Nano-cerium oxide, L-arginine and their combination on the hepatic and renal toxicity of monosodium glutamate in male Swiss albino mice using histological, as well as histochemistry examinations and histomorphometrical analysis.

\section{MATERIALS AND METHODS}

\subsection{Chemicals}

1. Monosodium Glutamate (MSG) salt (Shanghai Bio Life Science \& Technology Co., Ltd. (China)) was fresh prepared by dissolved in distilled water to prepare desired dose $4 \mathrm{mg} / \mathrm{kg} . \mathrm{bw}$ according to Eman et al.,$^{[11]}$ for oral administration by oral gavage via metal intragastric tube for 14 days.

2. Cerium oxide nanoparticles (Sigma Aldrich (St. Louis, MO, USA)), its particle size was Nano powder, $<25 \mathrm{~nm}$. It was freshly prepared in distilled water before uses to prepared used dose $(0.5 \mathrm{mg} /$ $\mathrm{kg}$, orally, antioxidant treatment dose) according to Hirst et al.,$^{[25]}$

3. L-Arginine (Cayman chemical company, USA) was fresh prepared by dissolved in distilled water to prepare desired dose $100 \mathrm{mg} / \mathrm{kg}$.bw according to Sánchez-Fidalgo, et al., ${ }^{[37]}$ to administrate orally by oral gavage via metal intragastric tube for 14 days.

\subsection{Animals and experimental design}

Fifty male Swiss albino mice aged $9-12$ weeks and weight $25-30 \mathrm{~g}$ were used in our study. They were obtained from the animal house of National Organization for Drug Control and Research (NODCAR) in Giza, Egypt. Mice were kept in plastic cages and supplied with standard commercial diet pellets and water that Ad-labium for 7 days to be accommodated with our laboratory conditions before treatment under proper conditions of light and temperature.

All male Swiss albino mice were grouped and housed in according to the guidelines of the institutional animal's ethics committee of national organization for drug control and research (NODCAR). In addition to, All experimental procedures were conducted in accordance with the ethical standards and were approved by the Institutional Animal Care and Use Committee (IACUC) at NODCAR (approval no. NODCAR/III/41/2019). Experimental animals were classified into the five groups, each group formed of 10 animals as follow:

Group I (Control group): animals treated orally with distil water ( $1 \mathrm{ml} / \mathrm{kg} . \mathrm{bw} /$ daily) 
Group II (Glutamate treated group): Each mouse was orally administrated with monosodium glutamate (4 mg/kg. bw.) according to Eman E. Ragab, 2018 $8^{[1]}$

Group III (Glutamate-Cerium treated group): Mice were orally administrated with both monosodium glutamate (4 mg/kg bw) and Nano-cerium oxide $(0.5 \mathrm{mg} / \mathrm{kg}$, orally, antioxidant treatment dose) according to Hirst et al., ${ }^{[25]}$.

Group IV (Glutamate-Arginine treated group): animals in this group simultaneous orally administrated with monosodium glutamate (4 $\mathrm{mg} / \mathrm{kg} \quad \mathrm{bw})$ and L-arginine $(100 \mathrm{mg} / \mathrm{Kg} \mathrm{bw})$ freshly prepared according to Sánchez-Fidalgo, et al., ${ }^{[37]}$.

Group V (Glutamate- Arginine-Cerium treated group): Each mouse was orally administrated with monosodium glutamate $(4 \mathrm{mg} / \mathrm{kg}$ bw), L-arginine $(100 \mathrm{mg} / \mathrm{Kg}$ bw) and Nano-cerium oxide $(0.5 \mathrm{mg} / \mathrm{kg}$, orally).

The experimental period was 14 days and at the end of the experimental periods, The animals are euthanized after $24 \mathrm{~h}$ of the last dose by decapitation after intraperitoneal injection of Sodium pentobarbital $(50 \mathrm{mg} / \mathrm{kg})$ dissection and freshly removed hepatic and renal tissues were freshly collected to preserve in $10 \%$ formalin for fixation for light microscopically examinations as:

1. Histological and histochemistry examinations

2. Histomorphometrical analysis

\section{Histological and histochemical investigations}

After 48 hours from fixation in $10 \%$ formalin, the specimens of renal and hepatic were washed, dehydrated in ascending grades of alcohol, cleared in xylene and embedded in paraffin wax. Five micron thick paraffin sections were prepared, mounted on clean slides and stained with Ehrlich's haematoxylin-eosin for histological study ${ }^{[38]}$, and Feulgen's reaction to demonstrate DNA content ${ }^{[39]}$.

\section{Histomorphometrical analysis}

The percentage areas of DNA content in hepatocyte of hepatic and epithelial cells lining real tubules of renal were measured using an objective lens of magnification X40, i.e. of total magnification X400. The intensity of DNA content were measured from randomly 10 hepatocyte in hepatic tissues/epithelial cells lining real tubules for randomly selected ten fields of hepatic and renal sections stained with feulgen's stain in each experimental groups using J-image program. Then and the mean values were calculated.

\section{Statistical analysis}

All values were expressed as mean \pm SD (stander division) for ten samples for each group. Values of $p<0.05$ were considered statistically significant. $P$ value $\geq 0.05$ was considered as statistically significant, while $P$ values $\geq 0.001$ were considered as highly significant. All statistics were carried out using GraphPad Prism software 5.01 (La Jolla, CA, USA).

\section{RESULTS}

\subsection{Histological examinations of hepatic tissues}

Control hepatic tissues showed normal hepatocyte radiated from central vein and separated by sinusoid (Figure 1a). However, monosodium glutamate treated animals revealed prominent areas of severe vacuolated hepatocyte with pyknotic nuclei, marked dilated central vein congested with hemolysis blood cells and perivascular inflammatory cells infiltrations (Figure 1b). Most portal areas revealed marked dilated portal vein congested with hemolysis blood cells, proliferation bile duct, and thickened wall of artery that surrounded by severe vacuolated hepatocyte with pyknotic nuclei as well as hemorrhage, and perivascular dense aggregation of inflammatory cells (Figure1 b1). More overe, large areas of dense aggregation of inflammatory cells and necrosis combined with dilated sinusoids were also noticed (Figure1 b2). Others areas, showed dispersed severe degenerated hepatocyte by hemorrhage and focally inflammatory cells infiltration (Figure1 b3).

Animals treated with monosodium glutamate and Nano-cerium oxide revealed normal reappearance of most hepatocyte, central vein and sinusoids in wide area (Figure 2a). However, some areas still showed mild to moderate congested dilated central vein, portal vein, intact bile duct, accompanied with moderate vacuolated hepatocyte with vesicular nucleus and perivascular mild inflammatory cells aggregation (Figure2 a1).

While, animals treated with monosodium glutamate and L-arginine revealed moderate improvement as revealed normal appearance of central vein, hepatocyte and sinusoids with focally dispersed inflammatory cells aggregation in some areas (Figure 2 b1). Moderate congested dilated portal vein, bile duct; inflammatory cells aggregation accompanied with normal hepatocyte with vesicular nucleus were also noticed (Figure 2 b2). Histological examination of hepatic section from mice treated with monosodium glutamate, Nano-cerium oxide and L-arginine restored normal histological architecture with normal appearance of central vein, hepatic cells, and sinusoids, with occasionally seen mild inflammatory cells aggregation in wide areas (Figure $2 \mathrm{c}$ ). Portal areas revealed intact portal vein and bile duct with mild perivascular inflammatory cells aggregation (Figure $2 \mathrm{c} 1$ ).

\subsection{Histological examinations of renal tissues}

Light microscopically examination of renal section from normal mice revealed normal histological structure of renal corpuscle containing the glomerulus tuft and surrounded by the Bowman's space. Intact renal tubules lining with normal epithelial cells with vascular nucleus were also seen (Figure 3A). In contrast, treatment with monosodium glutamate resulted in prominent areas from cluster of atrophied glomerulus tufts, and homogenous eosinophilia material in interstitial tissues, together with severe degenerative renal tubules with pyknotic nuclei of 
epithelial lining cells and scattered necrotic areas in renal tubule (Figure3B). Large areas, revealed marked atrophied glomerulus tufts with hyper-cellularity, degenerative renal tubules with hyaline cast in its lumen and pyknotic nuclei of epithelial lining cells. Severe dilated congested blood vessel, thickened wall of dilated congested artery accompanied with wide area of edema and hemorrhage in interstitial space with necrotic of some renal tubule were noticed. (Figure 3 B1). In some areas, hemorrhage and inflammatory cells aggregation in interstitial tissues (arrow head) with severe degenerative renal tubules were seen compared to control group (Figure 3 B2).

Sections of the renal from mice treated with monosodium glutamate and Nano-cerium oxide revealed normal histological structure of glomerulus tuft that surrounded by the Bowman's space and intact of most renal tubules with focally mild degenerative renal tubules (Figure 4 A1). Some area still revealed moderate reduction in size of glomerulus tuft, dilated congested blood vessels, eosinophilia material and, hemorrhage in interstitial tissues together with some renal tubules appeared normal and others revealed degenerative epithelial lining cells with pyknotic nuclei (Figure 4 A2). Similarly, hepatic section from mice treated with monosodium glutamate and L-Arginine showed same changes as previous group (Figure 4B \& B1) compared to glutamate treated group. When animals treated with monosodium glutamate, Nano-cerium oxide and L-Arginine, renal section revealed normal renal architecture as well as most of the renal corpuscle containing the glomerulus tuft and surrounded by the Bowman's space and Intact renal tubules lining with normal epithelial cells with vascular

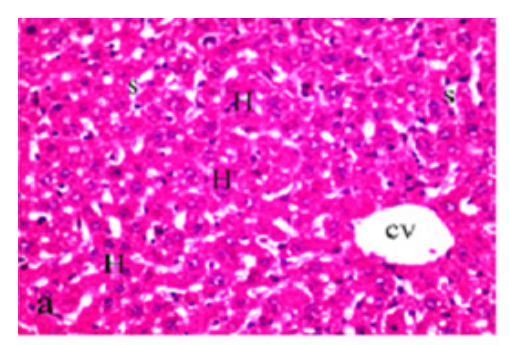

Figure 1
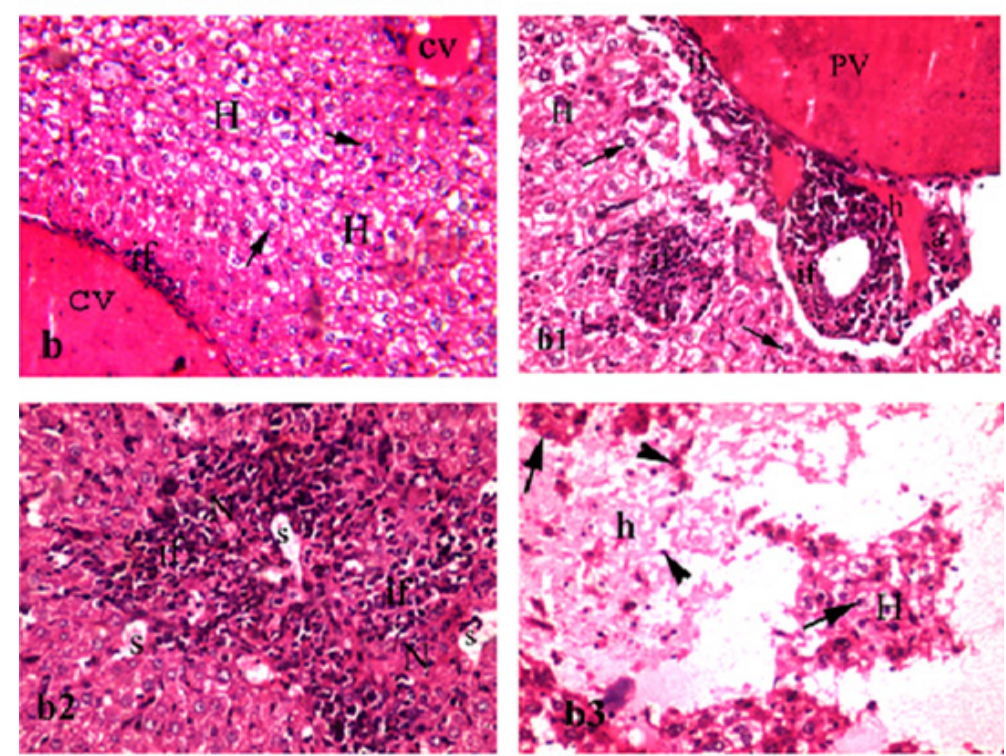

nucleus. However, focally renal tubules with pyknotic nuclei were still seen (Figure 4C) compared to glutamate treated group.

\subsection{Estimation of percentage area of DNA content in hepatic and renal tissues}

Table 1 and figure 5 and 6 expressed about percentage areas of DNA content in the hepatic and renal tissues in the different experimental groups. The monosodium glutamate treatment for two weeks revealed a highly significant decrease in the $\%$ areas of DNA content in the hepatic sections $(22.46 \pm 1.93)(P<0.05)$ and renal sections $(9.5 \pm 0.927)$ when compared to the control groups $(65.77 \pm 2.42,25 \pm 1.52$, respectively). Treatment with monosodium glutamate, Nano-cerium oxide and L-Arginine, was more effective than treatment with monosodium glutamate and Nano-cerium oxide or L-Arginine in increasing \% area of DNA content in the hepatic and renal tissues compared to glutamate treated group. When treatment with monosodium glutamate and Nano-cerium oxide or L-Arginine took place an significant increase in the \% area of DNA content was detected in hepatic $(50.986 \pm 4.51,52.93 \pm 2.13$, respectively) and renal tissues (17.25 $\pm 2.926,18.25 \pm 0.853$, respectively) comparison with the monosodium glutamate treated animals $(22.46 \pm 1.93$ and $9.5 \pm 0.927$, respectively). While monosodium glutamate, Nano-cerium oxide and L-Arginine treatment caused a highly significant increase in the $\%$ area of DNA content in hepatic (63.48 \pm 2.87$)$ and renal tissues $(23.5 \pm 2.03)$ when compared to monosodium glutamate treatment $(22.46 \pm 1.93$ and $9.5 \pm 0.927$, respectively). These increases come up to the same range of control value, but still insignificantly lower than the control.

Fig. 1: (a) A photomicrograph of a hepatic section from control mice showing normal hepatocyte $(\mathrm{H})$ radiated from central vein (CV) and separated by sinusoid (s). (b) A photomicrograph of a hepatic section from mice treated with monosodium glutamate showing severe vacuolated hepatocyte $(\mathrm{H})$ with pyknotic nuclei (arrow), marked dilated central vein congested with hemolysis blood cells (CV) and perivascular inflammatory cells infiltrations (if). (b1) A photomicrograph of a hepatic section from mice treated with monosodium glutamate showing portal area with marked dilated portal vein (PV) congested with hemolysis blood cells, proliferation bile duct (bd), and thickened wall of artery (a) and severe vacuolated hepatocyte $(\mathrm{H})$ with pyknotic nuclei (arrow) hemorrhage (h), and perivascular dense aggregation of inflammatory cells (if), were seen . (b2) A photomicrograph of a hepatic section from mice treated with monosodium glutamate showing large areas of dense aggregation of inflammatory cells (if) and necrosis $(\mathrm{N})$ with dilated sinusoids (s). (b3) A photomicrograph of a hepatic section from mice treated with monosodium glutamate showing dispersed severe degenerated hepatocyte with pyknotic nuclei (arrow) by hemorrhage (h) and focally inflammatory cells infiltration (arrow head). (H and E. X400) 

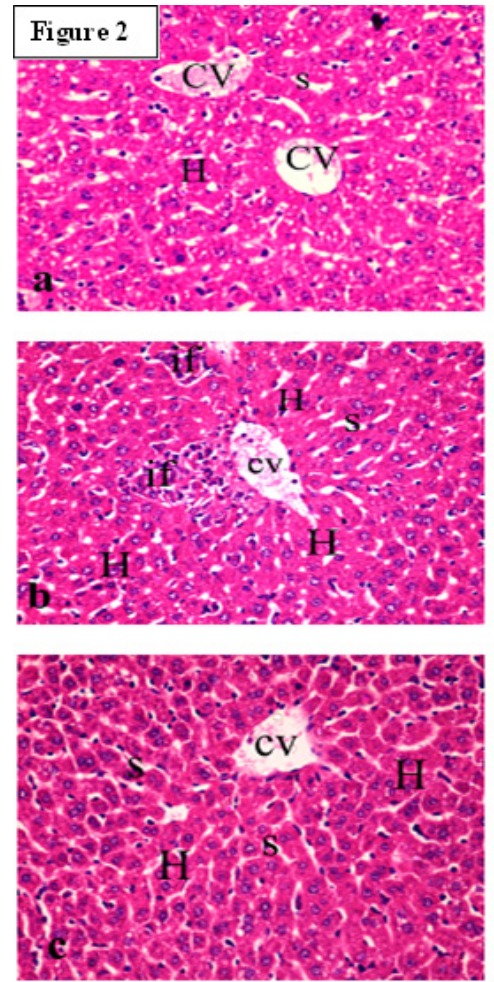
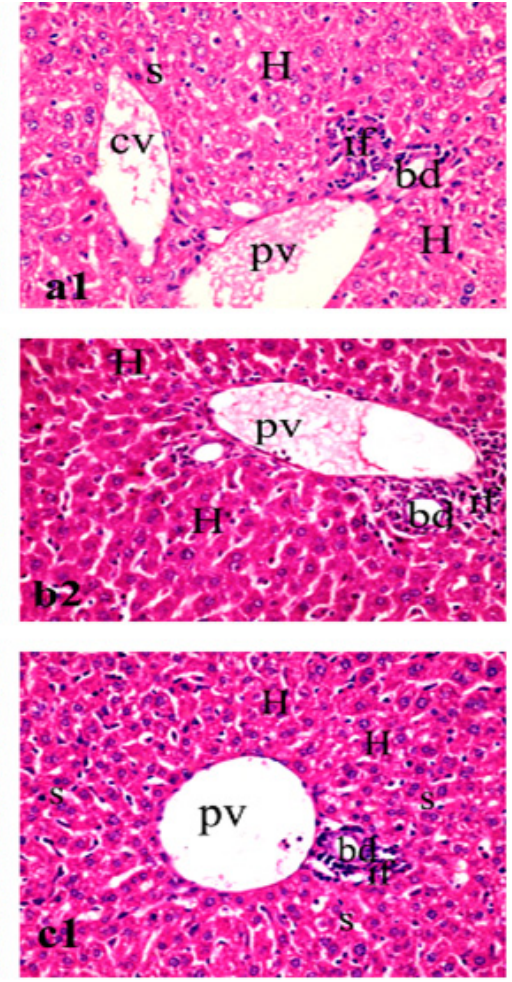

Fig. 2: (a) A photomicrograph of a hepatic section from mice treated with monosodium glutamate and Nano-cerium oxide showing normal reappearance of hepatocyte $(\mathrm{H})$, most central vein (CV) and sinusoids (s)., (a1) A photomicrograph of a hepatic section from mice treated with monosodium glutamate and Nanocerium oxide showing scattered areas with mild to moderate congested dilated central vein (cv), portal vein (pv), intact bile duct (b), accompanied with moderate vacuolated hepatocyte with vesicular nucleus $(\mathrm{H})$ and perivascular and mild inflammatory cells aggregation (if). (b) A photomicrograph of a hepatic section from mice treated with monosodium glutamate and L-arginine showing normal appearance of central vein $(\mathrm{cv})$, hepatocyte $(\mathrm{H})$ and sinusoids with focally dispersed inflammatory cells aggregation (if). (b1) A photomicrograph of a hepatic section from mice treated with monosodium glutamate and L-arginine showing some area with moderate congested dilated portal vein (pv), bile duct (bd), inflammatory cells aggregation (if) accompanied with normal hepatocyte with vesicular nucleus $(\mathrm{H})$. (c) A photomicrograph of a hepatic section from mice treated with monosodium glutamate, Nano-cerium oxide and L-arginine showing restore normal histological architecture of hepatic tissues with normal appearance of central vein (cv), hepatic cells (h), and sinusoids. (s), with occasionally seen mild inflammatory cells aggregation (if). (c1) A photomicrograph of a hepatic section from mice treated with monosodium glutamate, Nano-cerium oxide and L-arginine showing intact portal areas with intact portal vein (pv) and bile duct (bd) and mild perivascular inflammatory cells aggregation (if). (H and E. X400)
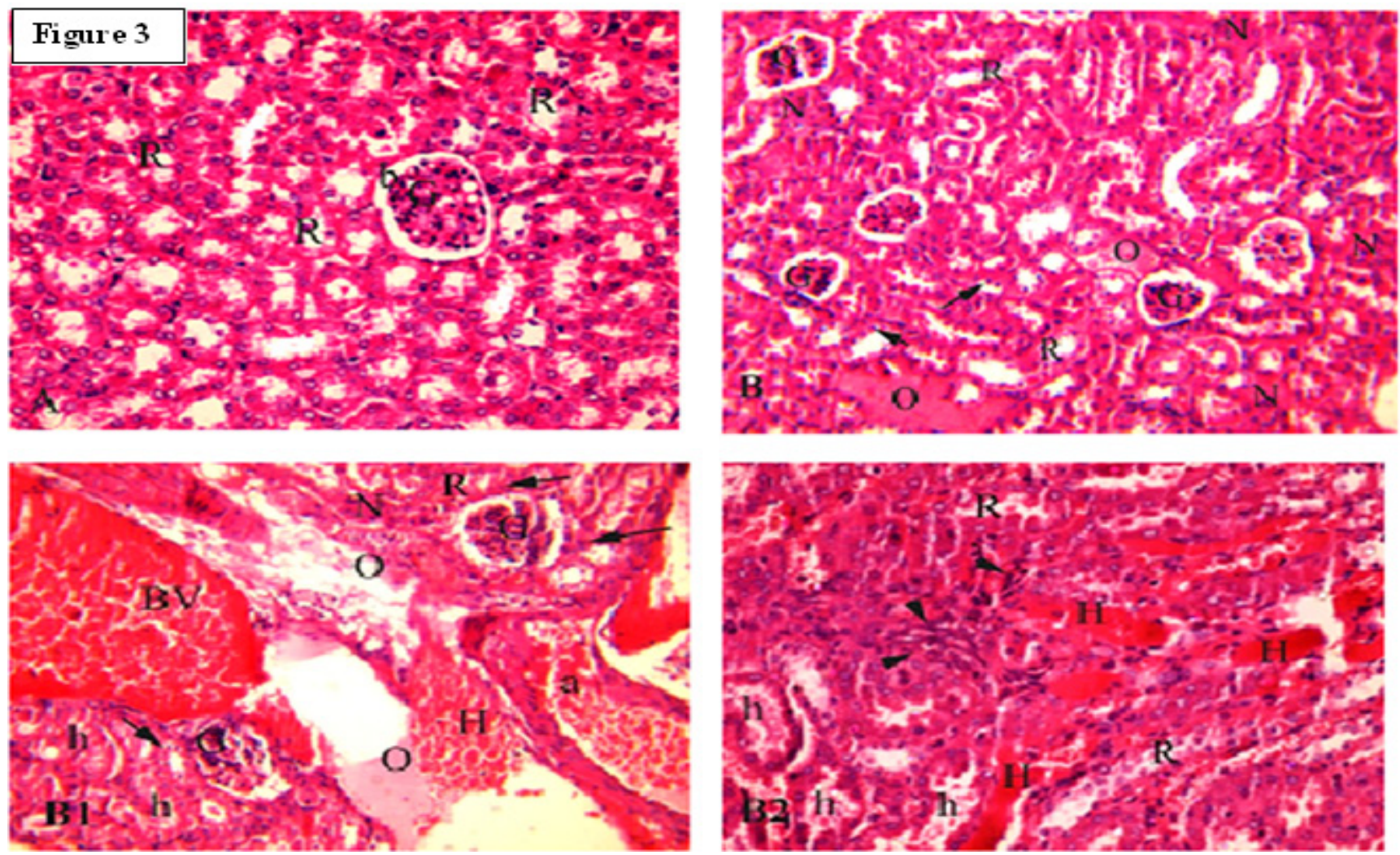

Fig. 3: (A) A photomicrograph of renal section from mice of control group showing normal histological structure with normal appearance of renal corpuscle containing the glomerulus tuft $(\mathrm{G})$ and surrounded by the Bowman's space (b). Intact renal tubules lining with normal epithelial cells with vascular nucleus (R) were seen. (B) A photomicrograph of renal section from glutamate-treated group showing prominent areas of cluster of atrophied glomerulus tufts (G), and homogenous eosinophilia material in interstitial tissues $(\mathrm{O})$, severe degenerative renal tubules $(\mathrm{R})$ with pyknotic nuclei of epithelial lining cells (arrow) and scattered necrotic areas in renal tubule $(\mathrm{N})$. (B1) A photomicrograph of renal section from glutamate-treated group showing marked atrophied glomerulus tufts with hyper-cellularity $(\mathrm{G})$, degenerative renal tubules with hyaline cast (h) in its lumen (R) and pyknotic nuclei of epithelial lining cells (arrow) accompanied with severe dilated congested blood vessel (BV), thickened wall of dilated congested artery (a). Wide area of edema (O) and hemorrhage in interstitial space (h) with necrotic of some renal tubule $(\mathrm{N})$ were noticed. (B2) A photomicrograph of renal section from glutamate-treated group showing hemorrhage (h), and inflammatory cells aggregation (arrow head) in interstitial tissues (arrow head) with severe degenerative renal tubules (R). (H and E. X400) 

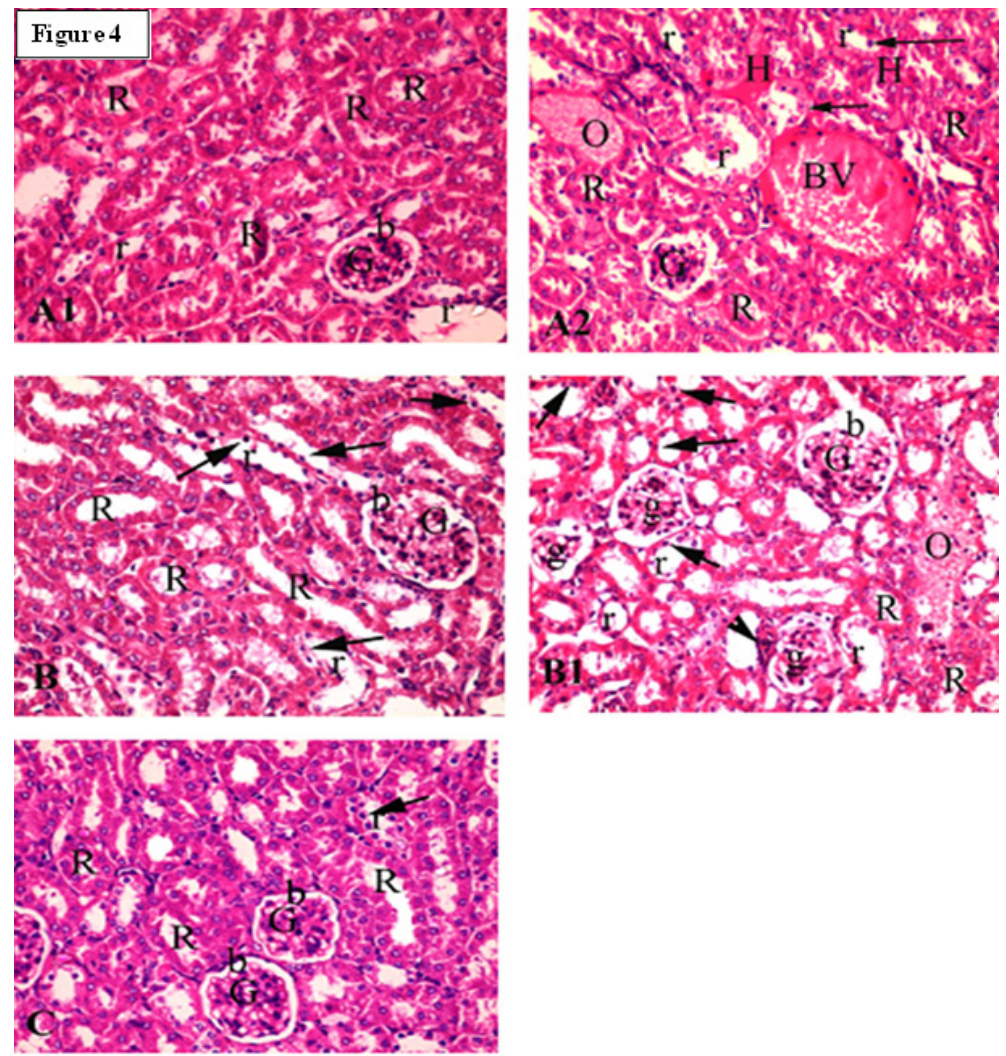

Fig. 4: (A1) A photomicrograph of renal section from glutamateCerium treated group showing normal histological structure of glomerulus tuft $(\mathrm{G})$ that surrounded by the Bowman's space (b) and intact of most renal tubules (R) with focally mild degenerative renal tubules (r). (A2) A photomicrograph of renal section from glutamate-Cerium treated group showing some area with moderate reduction in size of glomerulus tuft $(\mathrm{G})$, dilated congested blood vessels $(B V)$, eosinophilia material in interstitial tissues $(\mathrm{O})$, small area of hemorrhage between renal tubule $(\mathrm{H})$, some renal tubules appeared normal $(\mathrm{R})$ and others revealed degenerative epithelial lining cells with pyknotic nuclei (arrow).(B) A photomicrograph of renal section from glutamate-L-Arginine treated group showing normal histological architecture with normal glomerulus tuft (G) surrounded by the Bowman's space (b) and intact renal tubules (R), but few renal tubules ( $\mathrm{r}$ ) showed mild degenerative epithelial lining with pyknotic nuclei. (B1) A photomicrograph of renal section from glutamate-L-Arginine treated group showing areas of moderate to mild atrophied glomerulus tuft (g), eosinophilia material in interstitial tissues $(\mathrm{O})$ accompanied with few renal tubules appeared normal $(\mathrm{R})$ and others revealed degenerative epithelial lining cells with pyknotic nuclei (arrow). (c) A photomicrograph of renal section from mice treated with monosodium glutamate, Nano-cerium oxide and L-arginine showing normal appearance of renal corpuscle containing the glomerulus tuft $(\mathrm{G})$ and surrounded by the Bowman's space (b) and Intact renal tubules lining with normal epithelial cells with vascular nucleus (R). Focally renal tubules (r) with pyknotic nuclei (Head arrow) were seen. (H and E. X400)
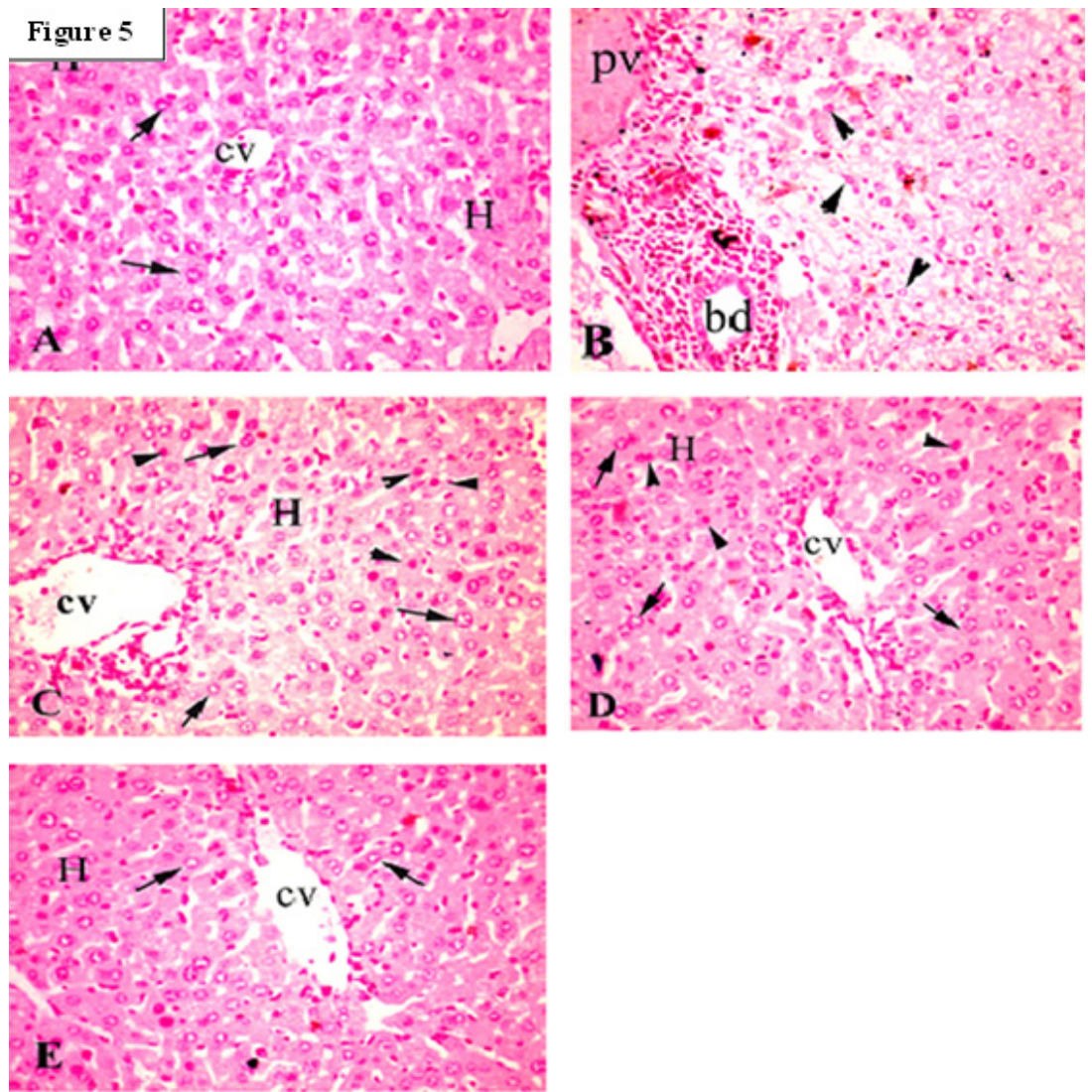

Fig. 5: Hepatic sections stained with Fulgent stain from: (a): A control mouse showing normal content of DNA (Arrow); (b) Monosodium glutamate treated mice showing decline in content of DNA in hepatocyte (arrow head); (c ) mouse treated with monosodium glutamate and cerium oxide nanoparticle; (d) mouse treated with monosodium glutamate and L-Arginine. And (E) mouse treated with monosodium glutamate, Nano-cerium oxide ;and L-Arginine. (Arrow): normal content of DNA; (arrow head): decline in DNA content: X200 

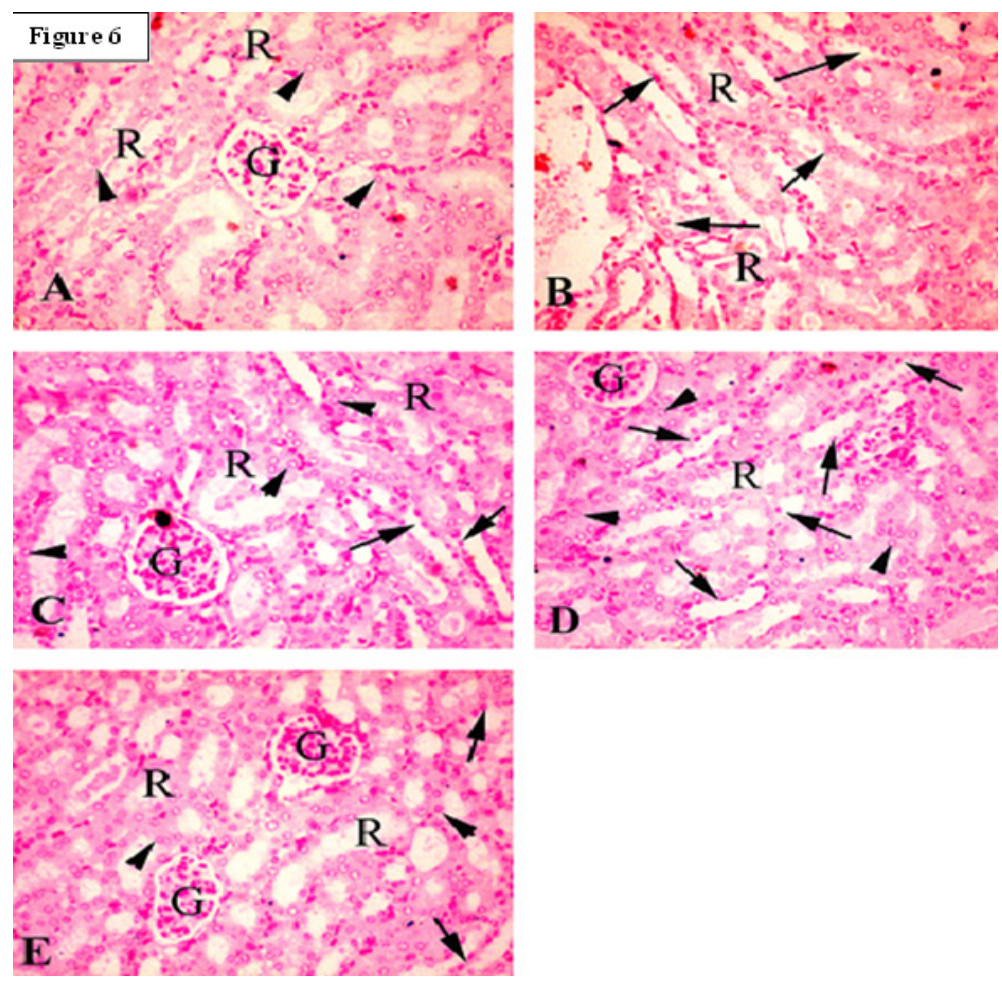

Fig. 6: renal Sections stained with Feulgen from: (a): A control mouse showing normal content of DNA (Arrow head); (b) Monosodium glutamate treated mice showing decline in content of DNA in epithelial cells lining renal tubules (arrow ); (c ) mouse treated with monosodium glutamate and cerium oxide nanoparticle; (d) mouse treated with monosodium glutamate and L-Arginine . And (E) mouse treated with monosodium glutamate, Nano-cerium oxide ;and L-Arginine. (Arrow head): normal content of DNA (arrow): decline in DNA content: X400

Table 1: Effect of monosodium glutamate alone, monosodium glutamate with cerium oxide nanoparticle or L-arginine and combination on the $\%$ areas of DNA content ( $\mathrm{mm} 2$ ) in the hepatic and renal tissues of male Swiss albino mice

\begin{tabular}{lcc}
\hline Parameters & \multicolumn{1}{c}{$\%$ areas of DNA content $\left(\mathrm{mm}^{2}\right)$} & renal \\
\hline \multirow{2}{*}{ Groups } & Hepatic & Mean \pm SD \\
\hline Control group & Mean \pm SD & $25 \pm 1.52^{\mathrm{a}}$ \\
Glutamate treated group & $65.77 \pm 2.42^{\mathrm{a}}$ & $9.5 \pm 0.927^{\mathrm{b}}$ \\
Glutamate-Cerium treated group & $22.46 \pm 1.93^{\mathrm{b}}$ & $17.25 \pm 2.926^{\mathrm{c}}$ \\
Glutamate-Arginine treated group & $50.986 \pm 4.51^{\mathrm{c}}$ & $18.25 \pm 0.853^{\mathrm{c}}$ \\
Glutamate- Arginine-Cerium treated group & $52.93 \pm 2.13^{\mathrm{c}}$ & $23.5 \pm 2.03^{\mathrm{a}}$ \\
\hline
\end{tabular}

In each group, five animals were used. Data are represented as mean \pm S.D. Means with same letter are not significantly different $(P<0.05)$ is significant and $(P<0.01)$ is highly significant

\section{DISCUSSION}

Monosodium glutamate is widely consumed in most foods as food additives in the world ${ }^{[40]}$, and mainly metabolism in the hepatic and excretion through the renal ${ }^{[41-42]}$. Therefore, our current study had evaluated the hepatic and renal toxicity of monosodium glutamate $(4 \mathrm{mg} / \mathrm{kg} \mathrm{b.w}$.) and the healing effect of Nano-cerium oxide, L-arginine and their combination in male Swiss albino mice using histological, histomorphometrical and histochemistry studies.

Results of our work have reported that administration of monosodium glutamate for two weeks is capable of induction variable histological alterations in both hepatic and renal tissues as evidence by scattered severe congested dilated blood vessels, severe inflammatory cells aggregations and vacuolated hepatocyte with pyknotic nuclei in hepatic while cluster of severe atrophied glomerular tufts, severe degenerative renal tubules, and wide areas of hemorrhage in interstitial tissues in the renal tissue. These were in agreement with work done by ${ }^{[1 ; 33 ; 43 ; 44]}$. The reason for these hepatic injuries is elevation of hepatic enzyme as serum aminotransferase alanine aminotransferase, and aspartate aminotransferase $\mathrm{e}^{[6 ; 33]}$. High serum levels of hepatic enzymes, as alanine aminotransferase and aspartate aminotransferase induced hepatocyte apoptosis and hepatic injury ${ }^{[45]}$ due to these enzymes are cytoplasmic and located into the circulation only after hepatocellular damage ${ }^{[46]}$.

Accumulation of glutamate in hepatocytes was proposed as the cause of degenerative changes and necrosis and its 
absorption and filtration through the renal artery leading to damages of the cells and the tubules ${ }^{[47]}$. In addition to, proliferation stem cells which line the bile ducts and lysis or necrosis hepatocyte could be the cause of proliferation bile duct observed in portal areas of hepatic tissues ${ }^{[48]}$.

In the current study, the observed and highly significant reduction of $\%$ areas of DNA content as well as injury of hepatic and renal tissue from glutamate treated group could be attributed to reactive oxygen species elevation ${ }^{[49]}$ decreasing total antioxidant capacities ${ }^{[33 ; 50]}$, the elevation malondialdehyde ${ }^{[49]}$, observed severe inflammation ${ }^{[51]}$. Chronic inflammation exerts its cellular side effects mainly through excessive production of free radicals and depletion of antioxidants ${ }^{[52]}$. Increasing of reactive oxygen species formation and the decrease in antioxidant enzymes lead to oxidative injury ${ }^{[33]}$. Malondialdehyde is a genotoxic by product through its binds to DNA, and damages it ${ }^{[54]}$.

Present study, also reported that administration of Nano-cerium oxide $(0.5 \mathrm{mg} / \mathrm{kg}$ bw) resulted in moderate improvement in the hepatic and renal injuries induced by monosodium glutamate toxicity as well as moderate increasing in DNA dimension. These could be attribute to its stronger antioxidant activities, elevate antioxidant enzymes as superoxide dismutase, catalyze and anti-apoptotic properties as well as suppress oxidative stress markers, and reactive oxygen species $(\mathrm{ROS})^{[21 ; 55-58]}$.

Pretreatment with Cerium oxide nanoparticle could be alleviated the immunoreactivity of caspase- 3 in cyclophosphamide-treated mice as recorded by Amiri, et al., ${ }^{[57]}$. Safety of cerium oxide nanoparticle application in medical applications were investigated in cellular function by Niu et al., ${ }^{[20]}$ Bagher et al., ${ }^{[5]}$.

Bagher et al., ${ }^{[58]}$, reported increase ferric reducing/ antioxidant power assay, total sulfhydryl content and decrease thiobarbituric acid reactive substances (indicator to level of malonaldehyde) as markers oxidative stress following administration of cerium oxide nanoparticle at doses 50,100, 200 and $400 \mathrm{mg} / \mathrm{kg}$ in rat. Niu et al., ${ }^{[20]}$; D'Angelo et al., ${ }^{[59]}$; Giri et al., 2013 ${ }^{[60]}$ reported that many oxidative stress-based animal model's diseases, as Alzheimer's, cardiomyopathy, and cancers can be ameliorate by cerium oxide nanoparticle.

In the current study, the observed ability of Nano-cerium oxide to contrast severe aggregation of inflammatory cells aggregation observed in monosodium glutamate hepatic and renal treated animals could be attributed to its antiinflammatory properties ${ }^{[61]}$, while its ability to significant increasing in DNA content that decrease by monosodium glutamate administration could be attributed to its high ability to suppress malonaldehyde activity in hepatic and renal tissues as recorded by Amiri et al., ${ }^{[57]}$; Bagher et al., ${ }^{[58] \text {, }}$ and scavenge free radical ${ }^{[21]}$

Esch et al. ${ }^{[62]}$, recorded that cerium oxide nanoparticle has high ability to neutralizing reactive oxygen species by its ability to bind to oxygen under reducing and oxidizing circumstances. Moreover, Popov et al., ${ }^{[6]}$;
Serebrovska et al., ${ }^{[64]}$; Shabrandi et al.. ${ }^{[63]}$, stated that antioxidants of cerium oxide nanoparticle could refer to their dual redox states on the surface. Nanoceria switches between $\mathrm{Ce}^{+}$and $\mathrm{Ce} 4^{+}$states and scavenges free ${ }^{[57]}$.

Likewise, treatment with L-Arginine caused moderate improvement in the histological alterations in hepatic and renal tissue induced by monosodium glutamate alone and significant improvement of DNA content. These were confirmed by work done by Elbassuonia et al., ${ }^{[33]}$, Salem et al. ${ }^{[66]}$. The reported ameliorating effect of L-Arginine in the present study may be attributed to increasing of total antioxidant capacity, and antioxidant as renal SOD activity (A. Gupta,2007) ${ }^{[67]}$ as well as decreasing ALT and AST levels (the hepatic injury markers), urea and creatinine (the renal injury markers) and oxidative stress through malonaldehyde decreasing ${ }^{[33]}$. Enhancement antioxidant enzymes of the renal and reduce the ROS production, these could aid to inhibit renal damage ${ }^{[68]}$.

Another reason for the beneficial effect of L-Arginine against toxicity of monosodium glutamate observed in the present study may be attributed to its indirect antioxidant effect through generation of $\mathrm{NO}^{[69-70]}$ which has antioxidant and anti-inflammatory activity ${ }^{[71]}$.

NO which interact with vascular smooth muscles, meningeal and tubular cells to control renal blood flow and glomeruli tubular functions ${ }^{[72]}$. It has antioxidant properties and ability to prevent oxidative stress in tissues through many mechanism such as interrupting chain reaction of lipid peroxidation ${ }^{[73]}$, or through initiate the expression of antioxidant enzymes or through finally enhances the antioxidant potency of GSH by forming S-nitrosoglutathione that is about 100 fold more potent than that of $\mathrm{GSH}^{[74,75]}$.

Combined treatments of Nano-cerium oxide and L-Arginine with Nano-cerium oxide and L-Arginine revealed marked improvement in histopathological alteration in hepatic and renal tissues induced by administration monosodium glutamate. They also resulted in highly significant increase in percentage area of DNA content compared to glutamate treated group. These suggest complete correction of the pathological changes observed in animals treated with monosodium glutamate when treated with Nano-cerium oxide and L-Arginine, these could be attributed to combined amelioration action of Nano-cerium oxide and L-Arginine.

\section{CONCLUSIONS}

This study found that the uses of Nano-cerium oxide combined with L-arginine more effective than uses Nanocerium oxide or L-arginine alone in improving renal injuries, hepatic damage induced by common uses of monosodium glutamate. Administration of Nano-cerium oxide or L-argentine alone induced ameliorations of the hepatic and renal histological altersions induced by oral supplementation of monosodium glutamate but some pathological changes still present. They also caused moderate improvement in the DNA content but still not reaches to normal value as revealed by histomorphometricl analysis. Combined 
administration of Nano-cerium oxide and L-arginine caused marked ameliorations of the hepatic and renal changes induced by monosodium glutamate as revealed by restore normal appearance of renal and hepatic tissues and return DNA content to reach to normal value. Therefore, we recommended the combined use of Nano-cerium oxide and L-arginine as a curative approach for monosodium glutamate induced hepatic and renal injuries.

\section{CONFLICTS OF INTEREST}

There are no conflicts of interest.

\section{REFERENCES}

1. Afeefy A, Mahmoud M and Arafa M. (2012): Effect of honey on monosodium glutamate induced nephrotoxicity (histological and electron microscopic studies). Journal American Science.; 8(1s): 146-156.

2. Bera T K, Kar SK, Yadav P K, Mukherjee P, Yadav $\mathrm{S}$, Joshi B. Effects of monosodium glutamate on human health: A systematic review.( 2017): World Journal of Pharmaceutical Sciences.; 2321-3310: 2321-3086

3. Jinap S and Hajeb P. (2010): Glutamate, Its applications in food and contribution to health. Appetite.; 55: 1-10.

4. Kurihara K.( 2009): Glutamate: from discovery as a food flavor to role as a basic taste (umami). Am J Clin Nutri.; 90: 719S-22S.

5. Leung AY, Foster S. (2003):Monosodium glutamate. Encyclopedia of Common Natural Ingredients: Used in Food, Drugs, and Cosmetics ( $2^{\text {nd }}$ Ed.). New York: Wiley.: 373-375. ISBN 978-0-471-47128-8, 2003.

6. Eweka A, Igbigbi P, Ucheya R. (2011): Histochemical studies of the effects of monosodium glutamate on the hepatic of adult wistar rats, Ann. Med. Health Sci. Res.; 1 :21-29.

7. Bojanic V, Bojanic Z, Najman S, Savic T, Jakovljevic $\mathrm{V}$, et al. (2009): Diltiazem prevention of toxic effects of monosodium glutamate on ovaries in rats. Gen Physiol Biophys.: 149-154.

8. He K, Zhao L, Daviglus ML, Dyer AR, Van Horn L, Garside D, Zhu L, Guo D, Wu Y, Zhou B, Stamler J. (2008): Association of monosodium glutamate intake with overweight in Chinese adults: the INTERMAP Study. Obesity;16(8):1875-1880.

9. Shi Z, Luscombe-Marsh ND, Wittert GA, Yuan B, Dai Y, Pan X, Taylor AW.( 2010): Monosodium Glutamate is not associated with obesity or a greater prevalence of weight gain over 5 years: findings from the Jiangsu Nutrition Study. Br J Nutr.;104 (3):457-463.

10. Onaolapo1 AY, Onaolapo OJ, Mosaku TJ, Akanji OO and Abiodun O. (2013): A Histological Study of the Hepatic and Renal Effects of Subchronic Low Dose Oral Monosodium Glutamate in Swiss Albino Mice. British Journal of Medicine \& Medical Research. ; 3(2): 294-306, SCIENCEDOMAIN international www.sciencedomain.org

11. Ragab E E,( 2018): The possible protective effect of vitamin $\mathrm{C}$ on monosodium glutamate induced renal toxicity in male albino rats. Egyptian journal of histology:; 386-396.

12. Egbuonu1 CC, Obidoa O, Ezeokonkwo $\mathrm{C}$ A, Ezeanyika LU S and Ejikeme $\mathrm{P} M$. (2009): Hepatotoxic effects of low dose oral administration of monosodium glutamate in male albino rats. African Journal of Biotechnology.; 8 (13), : 3031-3035, 6 July, Available online at http://www.academicjournals.org/AJB

13. Kumbhare V, Gajbe U, Singh B R, Reddy AK, Shukla S. (2015): Histological \& histochmical changes in hepatic of adult rats treated with monosodium glutamate: a light microscopic study. World Journal of Pharmacy and Pharmaceutical Sciences.; 4 (4): 898-91.

14. Hagan CT, Medik YB, Wang AZ, (2018): Nanotechnology Approaches to Improving Cancer Immunotherapy. Adv Cancer Res.; 139:35-36.

15. Sridharan K. (2018): Emerging Trends of Nanotechnology in Environment and Sustainability: A Review-Based Approach. Springer;.

16. Nourmohammadi E, Oskuee RK, Hasanzadeh L, et al.( 2018): Cytotoxic activity of greener synthesis of cerium oxide nanoparticles using carrageenan towards a WEHI 164 cancer cell line. Ceram Int.;44(16): 19570-19575. doi:10.1016/j.ceramint.2018.07.201

17. Reed K, Cormack A, Kulkarni A, et al.( 2014): Exploring the properties and applications of nanoceria: is there still plenty of room at the bottom? Environ Sci Nano.;1(5):390-405.

18. Hasanzadeh L, Oskuee RK, Sadri $\mathrm{K}$, et al. (2018): Green synthesis of labeled $\mathrm{CeO} 2$ nanoparticles with $99 \mathrm{mTc}$ and its biodistribution evaluation in mice. Life Sci.;212:233-240. doi:10.1016/j.lfs.2018.10.010

19. Izu N, Shin W, Matsubara I, Murayama N.( 2004): Development of resistive oxygen sensors based on cerium oxide thick film. J Electroceramics; 13(3-1): 706-713. doi:10.1007/s10832-004-5179-7

20. Niu J, Azfer A, Rogers LM, Wang X, Kolattukudy PE.( 2007): Cardioprotective effects of cerium oxide nanoparticles in a transgenic murine model of cardiomyopathy. Cardiovasc Res;; 73(3):549-559.doi:10.1016/j.cardiores.2006.11.031 
21. Hamzeh M, Amiri FT, Beklar SY, Hosseinimehr SJ.( 2018): Nephroprotective effect of cerium oxide nanoparticles on cyclophosphamide-induced nephrotoxicity via anti-apoptotic and antioxidant properties in BALB/c mice. Marmara Pharm J; 22(2): 180-9.

22. Kong L, Cai X, Zhou X, Wong LL, Karakoti AS, Seal S, et al.,( 2011): Nanoceria extend photoreceptor cell lifespan in tubby mice by modulation of apoptosis/survival signaling pathways. Neurobiol Dis.; 42(3): 514-23. [CrossRef]

23. Ramesh A, Ratla NN, Indukur R, (2014): Acute and sub-acute oral toxicity assessment of the cerium oxide nanoparticles in wistar rats. Int J Pharmacol.;5(1):46-50.

24. Wong LL, Hirst SM, Pye QN, Reilly CM, Seal S, McGinnis JF. ( 2013): Cata $\neg$ lytic nanoceria are preferentially retained in the rat retina and are not cytotoxic after intravitreal injection. PLoS One.;8(3):e58431.

25. Hirst SM, Karakoti AS, Tyler RD, Sriranganathan N, Seal S, Reilly CM. (2009):Antiinflammatory properties of cerium oxide nanoparticles. Small;5(24):2848-2856. doi:10.1002/smll.200901048.

26. Khorrami MB, Sadeghnia HR, Pasdar A, GhayourMobarhan M, Riahi-Zanjani B, Hashemzadeh A, Zare M, Darroudi M, (2019): Antioxidant and toxicity studies of biosynthesized cerium oxide nanoparticles in rats. International Journal of Nanomedicine;:14 2915-2926

27. Srinivas A, Rao PJ, Selvam G, Murthy PB, Reddy PN, (2011): Acute inhalation toxicity of cerium oxide nanoparticles in rats. Toxicol Lett.;205(2): 105-115. doi:10.1016/j.toxlet.2011.05.1027

28. Amiri FT, Hamzeh M, Beklar SY, Hosseinimehr S J, (2018):Anti-apoptotic and Antioxidant Effect of Cerium Oxide Nanoparticles on Cyclophosphamide-Induced Hepatotoxicity. Erciyes Med J; 40(3): 148-54 • DOI: 10.5152/etd.2018.0016

29. Lin Y, Wang LN, Xi YH, et al. (2008): L-arginine inhibits isoproterenol-induced cardiac hypertrophy through nitric oxide and polyamine pathways. Basic Clin Pharmacol Toxicol.; 103(2): 124-130, doi: 10.1111/j.1742-7843.2008.00261.x, indexed in Pubmed: 18816294.

30. Hou Y, Wu G, (2017) Nutritionally nonessential amino acids: a misnomer in nutritional sciences. Adv Nutr 8:137-139. doi:10.3945/ an.116.012971

31. Popolo A, Adesso S, Pinto A, Autore G, Marzocco S, (2014) : L-Arginine and its metabolites in renal and cardiovascular disease, Amino Acids, 46 : 2271-2286.
32. Tan B, Li XG, Kong X, Huang R, Ruan Z, Yao K, Deng Z, Xie M, Shinzato I, Yin Y, Wu G, (2009): Dietary 1-arginine supplementation enhances the immune status in early-weaned piglets, Amino Acids 37 323-331.

33. Elbassuonia EA, Ragya MM, Ahmedb S M. ( 2018): Evidence of the protective effect of L-arginine and vitamin D against monosodium glutamate-induced hepatic and renal dysfunction in rat. Biomedicine \& Pharmacotherapy.; 108:799-808.

34. Sellmann C, Degen C, Jin CJ, Nier A, Engstler A J, Alkhatib DH, De Bandt J-P, Bergheim I, (2017): Oral arginine supplementation protects female mice from the onset of non-alcoholic steatohepatitis Amino Acids; 49:1215-1225 DOI 10.1007/s00726-017-2423-4

35. Rikalo NA, Romanenkov IV, (2018): morphological changes in renal tissues of rats with acute ethanolinduced injury and after drug correction.Journal of Education, health and sport; 18(2),

36. Badawoud MH, Elshal EB, Zaki AI, Amin HA, (2018): The possible protective effect of L-arginine against 5-fluorouracil-induced nephrotoxicity in male albino rats. Folia Morphol;76 (4): 608-619. DOI: 10.5603/FM.a2017.0037Copyright (C) 2017 Via MedicaISSN 0015-5659www.fm.viamedica.pl

37. Sánchez-Fidalgo S, Martín-Lacave I, Illanes M, Bruseghini L, Esteras A and Motilva V, (2005): Administration of L-arginine reduces the delay of the healing process caused by ibuprofen. Implication of COX and growth factors expression. Histology and Histopathology; 20: 437-447.

38. Bancroft J, Gamble A, (2008): A Theory and Practice of Histological Techniques. $6^{\text {th }}$ ed. Chuchil Livingstone, New York, London; pp: 165-175.

39. Bancroft J. and Gamble M. (2002): "Theory and Practice of Histological Techniques." $5^{\text {th }}$ (Ed.), Churchil Livingstone, London.

40. Joint FAO/WHO Expert Committee on Food Additives (JECFA) Evaluation of certain food additives: sixty-third report of the Joint FAO/ WHO Expert Committee on Food Additives. WHO technical report series. 2004;928:108.

41. Onyema, OO, Farombi EO, Emerole GO, Ukoha AI, Onyeze GO.( 2006): Effects of vitamin E on monosodium glutamate induced hepatotoxicity and oxidative stress in rats. Indian J. Biochem. Biophys., 43: 20-24.[PubMed]

42. Collison KS, Maqbool Z, Saleh SM, Inglis A, Makhoul NJ, Bakheet R, et al. (2009): Effect of dietary monosodium glutamate on trans-fat-induced nonalcoholic fatty hepatic disease. J Lipid Res;50(8):1521-37. 
43. El-Helbawy N F, Radwan DA, Salem M F, El-Sawaf M E. (2017): Effect of monosodium glutamate on body weight and the histological structure of the zona fasciculata of the adrenal cortex in young male albino rats.Tanta Medical Journal, 45:104-113

44. Diab A E-AA And Hamza R Z. ( 2016): Monosodium Glutamate Induced Hepatotoxicity and the Possible Mitigating Effect of Vitamin $\mathrm{C}$ and Propolis. Journal of Advances in Medical and Pharmaceutical Sciences.; 7(4): 1-10.

45. Jiang ZQ, Yao Z H, Deng Z T, Jiang X C, Yan X J and Chen W P . (2013). Study on antagonistic effect of liangxue huayu recipe on endoplasmic reticulum stress-induced L02 hepatocyte apoptosis and its mechanism. Zhongguo Zhong Yao Za Zhi., 38(20): 3544-3548.

46. Boutry $\mathrm{C}$, Bos $\mathrm{C}$, Matsumoto $\mathrm{H}$, Even $\mathrm{P}$, Azzout-Marniche D, Tome D, Blachier F. (2011): Effects of monosodium glutamate supplementation on glutamine metabolism in adult rats. Front. Biosci. (Elite Ed.) 3: 279-290.

47. Walker R, Lupien JR.( 2000): The safety evaluation of monosodium glutamate, J. Nutr.; 130: 1049-1052.

48. Schaff Z, Nagy P.( 2004): Novel factors playing a role in the pathomechanism of diffuse hepatic diseases: apoptosis and hepatic stem cells, Orv. Hetil. 145: 1787-1793.

49. Thomas M, Sujatha KS, George S. (2009):Protective effect of Piper longum Linn on monosodium glutamate induced oxidative stress in rats, Indian J. Exp. Biol. 47:186-192.

50. Tawfik MS, Al-Badr N. ( 2012): Adverse effects of monosodium glutamate on hepatic and renal functions in adult rats and potential protective effect of vitamins C and E. Food Nutr. Sci. 03 :5- 9.

51. Abass M, El-Haleem MA. ( 2011): Evaluation of monosodium glutamate induced neurotoxicity and nephrotoxicity in adult male albino rats, J. Am. Sci. 7 :264-276.

52. Hold, G. L. and El-Omar, M. E. (2008). Genetic aspects of inflammation and cancer. Biochem J., 410(2): 225-235

53. Evans, M. D.; Dizdaroglu, M. and Cooke, M. S. (2004):Oxidative DNA damage and disease: induction, repair and significance. Mutat. Res., 567: 1-61.

54. Eder, E.; Wacker, M.; Lutz, U.; Nair, J.; Fang, X.; Batsch, H.; Beland, F.A.; Schlatter, J. and Lutz,W.K. (2006) : Oxidative stress related DNA adducts in the hepatic of female rats fed with sunflower, rapeseed, olive or coconut oil supplemented diets. Chem. Biol. Interact., 159: 81-89.
55. Colon J, Hsieh N, Ferguson A, Kupelian P, Seal S, Jenkins DW, et al. (2010): Cerium oxide nanoparticles protect gastrointestinal epithelium from radiation-induced damage by reduction of reactive oxygen species and upregulation of superoxide dismutase 2. Nanomedicine; 6(5): 698-705. [CrossRef]

56. Hashem RM, Rashd LA, Hashem KS, Soliman HM. (2015): Cerium oxide nanoparticles alleviate oxidative stress and decreases Nrf-2/HO-1 inD-GALN/LPS induced hepatotoxicity. Biomed Pharmacother;73: 80-6. [CrossRef]

57. Amiri FT, Hamzeh M, Beklar SY, Hosseinimehr S J.( 2018): Anti-apoptotic and Antioxidant Effect of Cerium Oxide Nanoparticles on Cyclophosphamide-Induced Hepatotoxicity. Erciyes Med. J; 40(3): 148-154• DOI: $10.5152 /$ etd.2018.0016

58. Khorrami M B, Sadeghnia H R, Pasdar A, Mobarhan M G, Zanjani B R, Hashemzadeh A, Zare M, Darroud M. (2019): Antioxidant and toxicity studies of biosynthesized cerium oxide nanoparticles in rats. International Journal of Nanomedicine; 14 : 2915-2926.

59. D'Angelo B, Santucci S, Benedetti E, et al.( 2009): Cerium oxide nanopar $\neg$ ticles trigger neuronal survival in a human Alzheimer disease model by modulating BDNF pathway. Curr Nanosci. 5(2):167-176. doi:10.2174/157341309788185523

60. Giri S, Karakoti A, Graham RP, et al. (2013): Nanoceria: a rare-earth nanopar $\neg$ ticle as a novel anti-angiogenic therapeutic agent in ovarian cancer. PLoS One.;8(1):e54578. doi:10.1371/journal. pone. 0054578

61. Hirst SM, Karakoti AS, Tyler RD, Sriranganathan N, Seal S, Reilly CM. (2009): Anti-inflammatory properties of cerium oxide nanoparticles. Small.; 5(24): 2848-2856. doi:10.1002/smll.200901048

62. Esch F, Fabris S, Zhou L, et al. (2005): Electron localization determines defect formation on ceria substrates. Science.;309(5735):752-755. doi:10.1126/science. 1111568

63. Shabrandi A, Azizi S, Hobbenaghi R, Ownagh A, Keshipour S. (2017): The healing effect of chitosan supported nano-CeO2 on experimental excisional wound infected with pseudomonas aeruginosa in rat. Iran J Vet Surg.;12(2):9-20.

64. Serebrovska Z, Swanson R, Portnichenko V, et al. (2017): Anti-inflammatory and antioxidant effect of cerium dioxide nanoparticles immobilized on the surface of silica nanoparticles in rat experimental pneumonia. Biomed Pharmacother.; 92:69-77. doi:10.1016/j. biopha.2017.05.064 
65. Popov A, Popova N, Tarakina NV, et al. (2018): Intracellular dehepaticy of antioxidant $\mathrm{CeO} 2$ nanoparticles via polyelectrolyte microcapsules. ACS Biomater Sci Eng. 4:2453-2462. doi:10.1021/acsbiomaterials. 8b00489

66. Salem NA, Salem EA, Maarouf AM, Kamel M, Elgalaly H, Radwan M, El-Dayem WA, Eladl M. (2010):Protective effect of trapidil and 1-arginine against renal and hepatic toxicity induced by cyclosporine in rats. Ren Fail.; 32(8):959-68. doi: 10.3109/0886022X.2010.501933.

67. Gupta A, Chander V, Sharma S, Chopra K. Sodium nitroprusside and 1-arginine attenuates ferric nitrilotriacetate-induced oxidative renal injury in rats, Toxicology. 2007; 232: 183-191.

68. Finch JL, Suarez EB, Husain K, Ferder L, Cardema MC, Glenn DJ, Gardner DG, Liapis H, Slatopolsky E. (2012):Effect of combining an ACE inhibitor and a VDR activator on glomerulosclerosis, proteinuria, and renal oxidative stress in uremic rats, Am. J. Physiol. Renal Physiol.; 302F141-149.

69. A. Lass, A. Suessenbacher, G. Wolkart, B. Mayer, F. Brunner. (2002): Functional and analytical evidence for scavenging of oxygen radicals by L-arginine, Mol. Pharmacol.; 61: 1081-1088.

70. Abo Zeid, El Saka MH, Shafik NM. (2012): Effect of combination of L-arginine and $\mathrm{N}$-acetyl cysteine in rat model of renal ischemia-reperfusion injury. J Am Sci.; 8(10): 814921, doi: 10.7537/j.issn.1545-1003.

71. Rusai K, Fekete A, Szebeni B, et al.( 2008): Effect of inhibition of neuronal nitric oxide synthase and L-arginine supplementation on renal ischaemiareperfusion injury and the renal nitric oxide system. Clin Exp Pharmacol Physiol.; 35(10): 1183-1189, doi: $10.1111 / \mathrm{j} .1440-1681.2008 .04976 . x$, indexed in Pubmed: 18518882.

72. Goligorsky MS,Brodsky SV, Noiri E. (2004): NO bioavailability, endothelial dysfunction, and acute renal failure: new insights into pathophysiology. Semin Nepherology.; (4):316-323.

73. Ling H, Edelstein C, Gengaro P, et al. ( 1999): Attenuation of renal ischemia-reperfusion injury in inducible nitric oxide synthase knockout mice. Am J Physiol.; 277(3 Pt 2): F383-F390, indexed in Pubmed: 10484522.

74. Klatt P, Lamas S. (2000): Regulation of protein function by S-glutathiolation in response to oxidative and nitrosative stress, Eur. J. Biochem.; 267: 4928-4944.

75. Matsubara A, Tamai K, Matsuda Y, Niwa Y, Morita H, Tomida K, Armstrong D, Ogura Y. (2005): Protective effect of polyethylene glycol-superoxide dismutase on leukocyte dynamics in rat retinal microcirculation under lipid hydroperoxide-induced oxidative stress, Exp. Eye Res.; 81:193-199. 


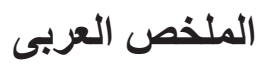

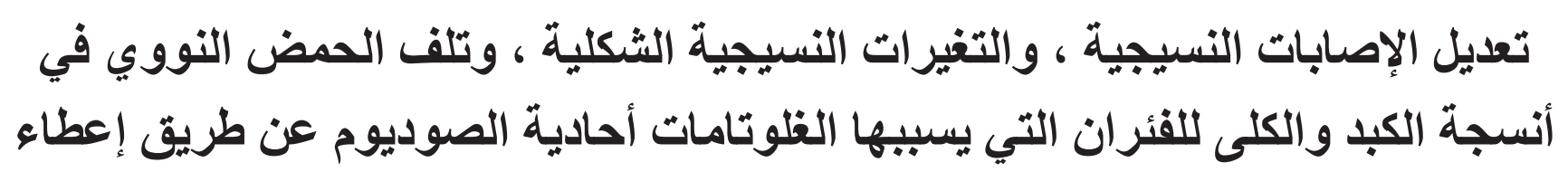
أكسيد النانو السيريوم او لـ أرجينين او استخدامهم مع بعض عن طريق الفم

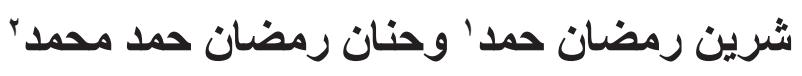

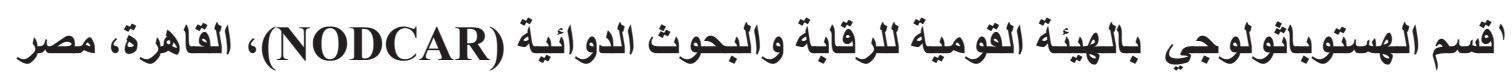

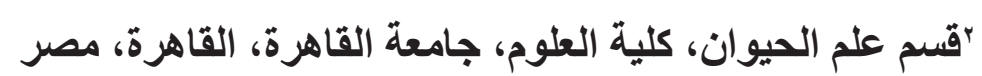

الخلاصة: يستخدم الغلوتامات أحادية الصوديوم على نطاق و اسع كمسن النكهة / المضافات الغذائية. أكدت العديد من الدراسات سمية الغلوتامات أحادية الصوديوم حتى لو كانت بتركيز ات منخفضة خاصة فئس في الأعضاء الكبدية و الكلى. لذلك ، هدفت دراستنا إلى فحص الدور التحسيني لأكسيد النانو السيريوم و L- أرجينين ومزيجهما على السئ السمية الكبدية

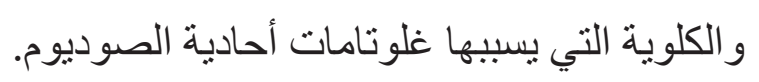

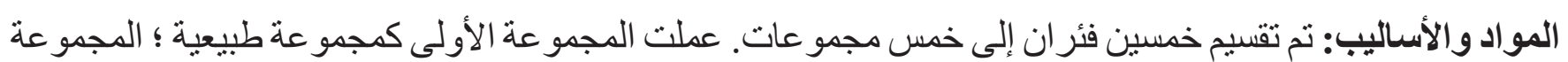

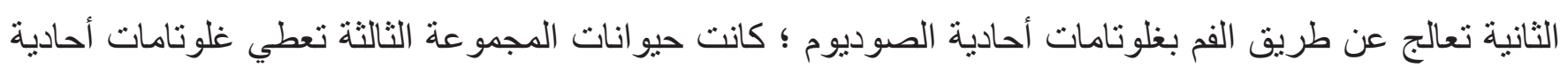

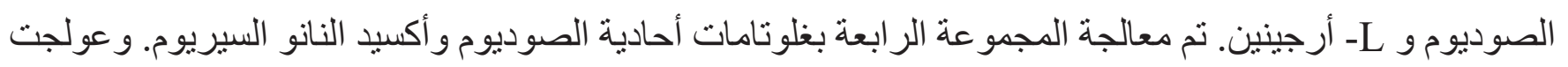

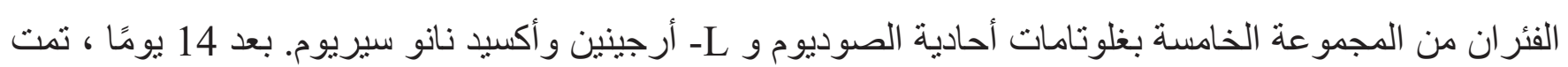

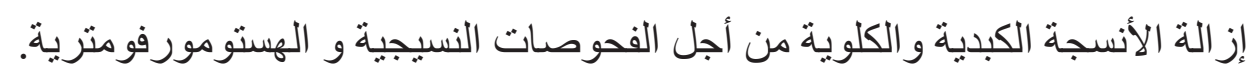

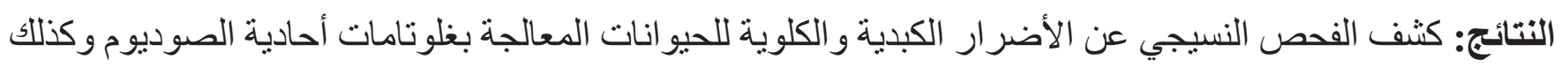

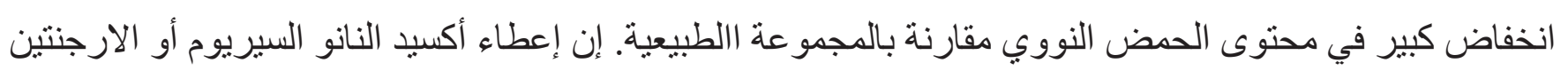

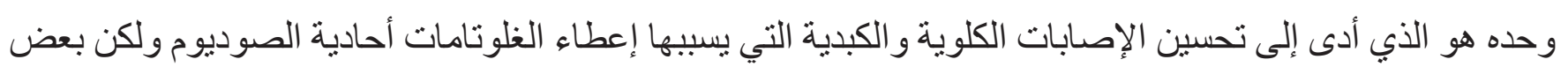

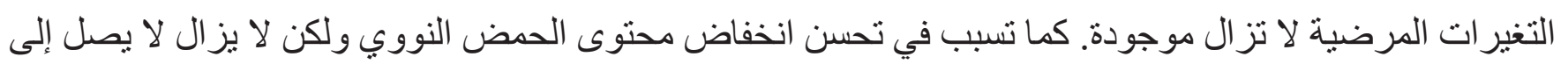

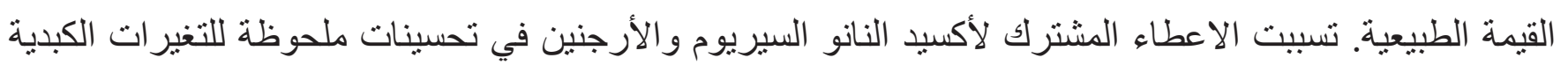
و الكلوية التي يسببها غلوتامات أحادية الصوديوم. الاستتتاجات: فإن الاستخدامات المشتركة لـ L - أرجينين و أكسيد نانو سيريوم أكثر فعالية في منع السمية الكبدية و الكلى التي يسبيها غلوتامات أحادية الصوديوم في ذكور الجرذان البيضاء من عند استخدامها بشكل منفصل. 